\title{
Control of Dimorphism in Candida albicans by Zinc: Effect on Cell Morphology and Composition
}

\author{
By H. YAMAGUCHI \\ Department of Microbiology, Faculty of Medicine, University of Tokyo, \\ Bunkyo-ku, Tokyo I I3, Japan
}

(Received 3 April 1974; Revised 7 October 1974)

Zinc participates in the morphogenesis of a wide range of micro-organisms. In several dimorphic fungi such as Histoplasma capsulatum (Pine \& Peacock, 1958), Mucor rouxii (Bartnicki-Garcia \& Nickerson, 1962) and Candida albicans (Widra, 1964), zinc completely reverses the filamentous or mycelial phase of growth. Fungal cultures in which the morphology is influenced by a single factor can be useful for the study of metabolic processes underlying the dimorphic phase conversion and in this paper the changes in some macromolecular constituents of $C$. albicans, associated with its morphological transformation, are described with respect to the concentration of zinc added to the defined basal medium.

\section{METHODS}

Candida albicans strain 6713, which forms extensive filaments under some nutritional conditions (Yamaguchi, I974a) was grown on a medium depleted of trace metals and containing (per l): glucose, $8 \mathrm{~g} ;\left(\mathrm{NH}_{4}\right)_{2} \mathrm{SO}_{4}, 8 \mathrm{~g} ; \mathrm{KH}_{2} \mathrm{PO}_{4}, 3.6 \mathrm{~g} ; \mathrm{Na}_{2} \mathrm{HPO}_{4}$. I $2 \mathrm{H}_{2} \mathrm{O}$, I. $2 \mathrm{~g}$; $\mathrm{MgSO}_{4} \cdot 7 \mathrm{H}_{2} \mathrm{O}, 0.2 \mathrm{~g}$; D-biotin, $0 . \mathrm{I} \mu \mathrm{g}$. In zinc-replete medium $\mathrm{ZnSO}_{4} \cdot 7 \mathrm{H}_{2} \mathrm{O}$ was added at $9 \mu \mathrm{M}$. Zinc-deficient medium was unsupplemented. Medium was inoculated (per ml) with about Io $\mu \mathrm{g}$ dry wt of $C$. albicans taken from the surface of a 2-day-old culture grown at $37^{\circ} \mathrm{C}$ on Sabouraud's glucose agar slants, washed three times with double-distilled water, and finally resuspended in water.

Growth conditions and methods for assay of dry weight, the proportion of yeastlike-phase (Y) cells to filamentous-phase (F) cells during growth, and the content of DNA, RNA and protein were as previously described (Yamaguchi, 1974a). DNA phosphorus and RNA phosphorus were calculated by using the atomic extinction coefficient for phosphorus proposed by Logan, Mannell \& Rossiter (I952). Insoluble inorganic polyphosphate in the hot I $\mathrm{M}-\mathrm{HClO}_{4}$ extract of the yeast was determined by adsorbing the nucleic acids on charcoal according to the method of Harold (I960), and the residual phosphorus, all of which was acid-labile, was taken as insoluble inorganic polyphosphate. After incinerating with conc. $\mathrm{H}_{2} \mathrm{SO}_{4}$ plus conc. $\mathrm{HNO}_{3}$, the resulting orthophosphate was determined by the method of Fiske \& SubbaRow (I925).

\section{RESULTS AND DISCUSSION}

The yield of $C$. albicans after $24 \mathrm{~h}$ growth was maximal with $3 \mu \mathrm{M}-\mathrm{Zn}^{2+}$; zinc above $10^{-5} \mathrm{M}$ was inhibitory to growth (Fig. I). Zinc-deficient cultures consisted almost entirely of F cells but the proportion of $Y$ cells increased with increasing concentrations of zinc, reaching a maximal level at $9 \mu \mathrm{M}-\mathrm{Zn}^{2+}$ (Fig. I). Observations with the light microscope agreed with these results, which were obtained using a mechanical filtration method. 


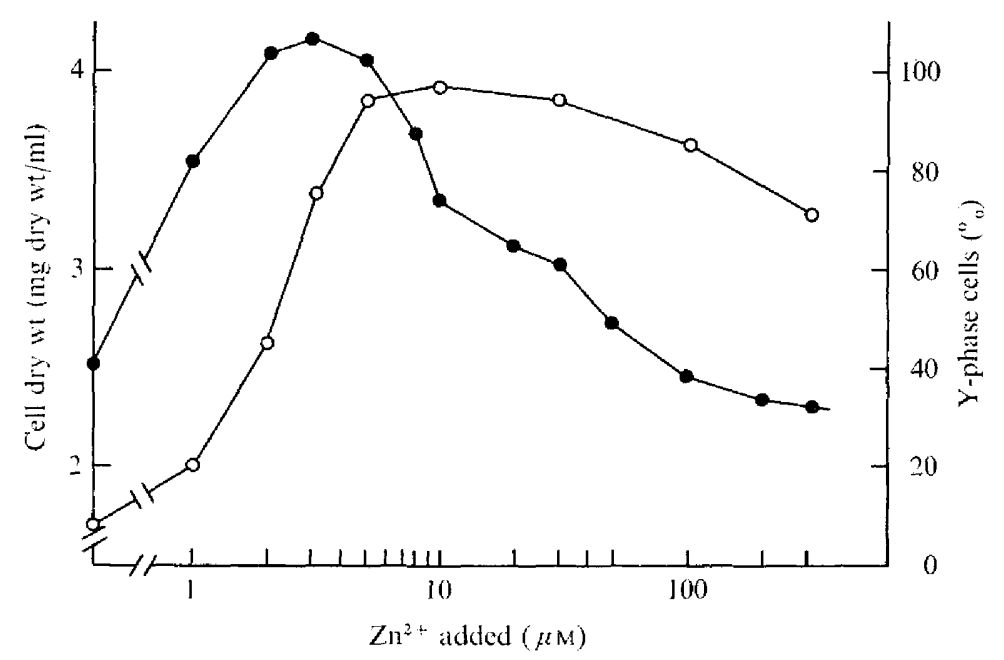

Fig. I. Effect of different concentrations of zinc added to medium on total growth and morphology of Candida albicans., , Dry wt of yeast; $O$, proportion of $\mathrm{Y}$ cells.

Table $\mathrm{x}$. Effect of zinc on the yield and concentrations of macromolecular constituents of Candida albicans during exponential and post-exponential growth

Content (per mg cell dry wt)

\begin{tabular}{|c|c|c|c|c|c|}
\hline $\begin{array}{l}\text { Age of } \\
\text { culture (h) }\end{array}$ & $\begin{array}{c}\text { Yield } \\
\text { (g dry wt/l) }\end{array}$ & $\begin{array}{l}\text { Protein } \\
(\mu \mathrm{g})\end{array}$ & $\begin{array}{l}\text { DNA } \\
(\mu \mathrm{g} P)\end{array}$ & $\begin{array}{c}\text { RNA } \\
(\mu \mathrm{g} \mathrm{P})\end{array}$ & $\begin{array}{l}\text { Polyphosphate } \\
\qquad(\mu \mathrm{g} \mathrm{P})\end{array}$ \\
\hline \multicolumn{6}{|c|}{$\mathrm{Zn}^{2+}$ added at $9 \times 10^{-6} \mathrm{M}$} \\
\hline 4 & 0.12 & 292 & 0.32 & $2 \cdot 84$ & $12 \cdot 8$ \\
\hline 8 & 0.59 & 290 & 0.17 & 3.00 & $12 \cdot 3$ \\
\hline 12 & $1 \cdot 92$ & 312 & 0.18 & 3.00 & $\mathrm{I} 2 \cdot \mathrm{I}$ \\
\hline 18 & 3.01 & 376 & 0.16 & $2 \cdot 62$ & - \\
\hline 24 & $3 \cdot 13$ & 405 & 0.19 & $2 \cdot 53$ & $12 \cdot 0$ \\
\hline \multicolumn{6}{|c|}{ No addition of $\mathrm{Zn}^{2+}$} \\
\hline 4 & $0.1 I$ & 273 & 0.35 & $3 \cdot 60$ & $16 \cdot 0$ \\
\hline 8 & 0.51 & 306 & 0.27 & $2 \cdot 43$ & I9. I \\
\hline 12 & 0.89 & 300 & 0.22 & $I .67$ & $20 \cdot 2$ \\
\hline 18 & $\mathrm{I} \cdot 75$ & 309 & $0.2 \mathrm{I}$ & 0.79 & - \\
\hline 24 & 2.08 & 314 & 0.23 & 0.69 & $20 \cdot 4$ \\
\hline
\end{tabular}

For the first $6 \mathrm{~h}$ of growth, zinc-deficient and zinc-replete cultures grew at the same rate with a doubling time of about $\mathrm{I} \cdot 5 \mathrm{~h}$. Subsequently, zinc-replete cultures still grew exponentially for about $5 \mathrm{~h}$ before slowing down, whereas the growth rate of zinc-deficient cultures dropped to about half but growth continued almost linearly at this rate for another I5 h. Growth of the deficient cultures over the latter period consisted essentially of filament elongation. It continued for at least $24 \mathrm{~h}$ after the yeast had reached its maximum dry weight.

Changes in content of several macromolecules were examined in both zinc-replete and zinc-deficient cultures (Table r). There was little difference between the two cultures in the protein and DNA contents throughout the growth phase. The concentrations of RNA and inorganic polyphosphate did not change significantly when there was an adequate concentration of zinc, but when zinc was deficient the RNA content fell to a third and the content of inorganic polyphosphate doubled during the post-exponential phase of growth. The 
inhibition of RNA synthesis and the accumulation of polyphosphate in the zinc-deficient cultures were apparent before inhibition of growth was observed.

The present data suggest that zinc has a primary function in metabolism of RNA in C. albicans, rather than protein or DNA. Zinc may be required for the synthesis of RNA or in preventing its degradation. Whatever the mechanism of action may be, the complete cessation of net RNA synthesis at the transitory stage from $\mathrm{Y}$ growth to $\mathrm{F}$ growth, under a certain degree of zinc deficiency, may imply that subsequent filamentous elongation takes place without net ribosomal formation. There is therefore a significant difference in the metabolic processes involved in mycelial elongation ( $F$ growth) and simple cell division ( $\mathrm{Y}$ growth). Low RNA concentrations and a high incidence of $\mathrm{F}$ forms also occur when C. albicans is grown with an insufficient supply of yeast extract (Yamaguchi, I974a) or biotin (Yamaguchi, 1974b).

Polyphosphate probably functions as store of 'high-energy' phosphate, as it may participate in the reversible synthesis of ADP and ATP (Yoshida \& Yamataka, 1953). The accumulation of polyphosphate in zinc-deficient cultures of $C$. albicans, therefore, suggests that cessation of both net RNA synthesis and growth is not due to a failure of energy-yielding metabolism. There may be an antagonism between polyphosphate and nucleic acid metabolism, each competing for ATP, as has been postulated by Smith, Wilkinson \& Duguid (1954) and Mudd, Yoshida \& Koike (1958). The physiological role of such metabolism of phosphorous compounds in the $F$ growth is being investigated.

I am grateful to Professor K. Iwata for valuable advice and to Miss Akiko Sawanobori for excellent technical assistance.

\section{REFERENCES}

Bartnicki-Garcia, S. \& Nickerson, W. J. (1962). Nutrition, growth, and morphogenesis of Mucor rouxii. Journal of Bacteriology 84, 841-858.

Fiske, C. H. \& SubbaRow, Y. (I925). The colorimetric determination of phosphorus. Journal of Biological Chemistry 66, 375-400.

HARold, F. M. (1960). Accumulation of inorganic polyphosphate in mutants of Neurospora crassa. Biochimica et biophysica acta 45, 172-188.

Logan, J. E., Mannell, W. A. \& Rossiter, R. J. (1952). A note on the determination of deoxypentose nucleic acid and pentose nucleic acid in tissue from the nervous system by ultraviolet absorption. Biochemical Journal 51, 480-482.

Mudd, S., Yoshida, A. \& Kolke, M. (1958). Polyphosphate as accumulator of phosphorus and energy. Journal of Bacteriology 75, 224-235.

PINE, L. \& PEACOCK, C. L. (I958). Studies on the growth of Histoplasma capsulatum. IV. Factors influencing conversion of the mycelial phase to the yeast phase. Journal of Bacteriology 75, I67-174.

Smith, I. W., Wilkinson, J. F. \& Duguid, J. P. (1954). Volutin production in Aerobacter aerogenes due to nutrient imbalance. Journal of Bacteriology 68, 450-463.

Widra, A. (1964). Phosphate directed Y-M variation in Candida albicans. Mycopathologia et mycologia applicata 23, 197-202.

YamaguChI, H. (1974a). Dimorphism in Candida albicans. I. Morphology-dependent changes in cellular content of macromolecules and respiratory activity. Journal of General and Applied Microbiology 20, 87-99.

Yamaguchi, H. (1974b). Mycelial development and chemical alteration of Candida albicans from biotin insufficiency. Sabouraudia (in the Press).

Yoshida, A. \& Yamataka, A. ([953). On the metaphosphate of the yeast. Journal of Biochemistry 40, 85-94. 
The insert enclosed in Volume 86, Part I, January (Fig. I. Matching matrix of the 98 test cultures based on 180 pooled characters) should be inserted in Volume 85, Part 2, December, facing p. 293. 


\section{Index of Authors}

Attwood, M. M., see Harder, W., Matin, A. \& AtTwood, M. M. Studies on the physiological significance of the lack of a pyruvate dehydrogenase complex of Hyphomicrobium sp. 319

AudhyA, T. K. \& Russell, D. W. Enniatin production by Fusarium sambucinum: primary, secondary, and unitary metabolism 327

Baker, D. A. \& PARK, R. W. A. Changes in morphology and cell wall structure that occur during growth of Vibrio sp. NCTC47 I6 in batch culture 12

BarnetT, J. A., Bascomb, S. \& Gower, J. C. A maximal predictive classification of Klebsielleae and of the yeasts 93

Bascomb, S., see Barnett, J. A., Bascomb, S. \& Gower, J. C. A maximal predictive classification of Klebsielleae and of the yeasts 93

BEEVER, R. E. Regulation of 2-phosphoenolpyruvate carboxykinase and isocitrate lyase syntheses in Neurospora crassa 197

Bhattacharjee, J. K., see Kurtz, M. Biosynthesis of lysine in Rhodotorula glutinis: role of pipecolic acid $\mathrm{IO}_{3}$

Briles, E. B. \& Tomasz, A. Physiological studies on the pneumococcal Forssman antigen: a cholinecontaining lipoteichoic acid 267

Brown, A. D. Microbial water relations. Effects of solute concentration on the respiratory activity of sugar-tolerant and non-tolerant yeasts 24I

Brown, C. M. \& Dilworth, M. J. Ammonia assimilation by Rhizobium cultures and bacteroids 39

BuhagIar, R. W. M. Torulopsis bacarum, Torulopsis pustula and Torulopsis multis-gemmis sp. nov. three new yeasts from soft fruit I

Bu'Lock, J. D., see Millonig, G., de Rosa, M., Gambacorta, A. \& Bu'Lock, J. D. Ultrastructure of an extremely thermophilic acidophilic microorganism 165

Bu'Lock, J. D., see de Rosa, M., Gambacorta, A. \& Bu'Lock, J. D. Extremely thermophilic acidophilic bacteria convergent with Sulfolobus acidocaldarius 156

Butcher, D. N., see Phillips, R. Attempts to induce tumours with nucleic acid preparations from Agrobacterium tumefaciens 3 I I

Caten, C. E., see Merrick, M.J. The inheritance of penicillin titre in wild-type isolates of Aspergillus nidulans 283

Child, J. J., see Sietsma, J. H., Child, J. J., NesBITT, L. R. \& HASKINS, R. H. Chemistry and ultrastructure of the hyphal walls of Pythium acanthicum 29

Coetzee, J. N. Chromosome transfer in Proteus mirabilis mediated by a hybrid plasmid 133

Coleman, G. \& Stormonth, D. A. Stimulation of the differential rate of exoenzyme formation in
Bacillus amyloliquefaciens by streptolydigin, an inhibitor of RNA chain elongation 194

COLES, R.S., Jun. The effect of coenzyme leakage and replacement on the growth and metabolism of two fusobacteria 147

Copland, H. J. R., see Moseley, B. E. B. Involvement of a recombination repair function in disciplined cell division of Micrococcus radiodurans 343

Datta, N., see Hedges, R. W., RodriguezLemoine, V. \& Datta, N. R factors from Serratia marcescens 88

Datta, N., see Rodriguez-Lemoine, V., JACob, A. E., Hedges, R. W. \& Datta, N. Thermosensitive production of their transfer systems by group $S$ plasmids I I I

Dilworth, M. J., see Brown, C. M. Ammonia assimilation by Rhizobium cultures and bacteroids 39

Ebringer, L., see Šmarda, J., Ebringer, L. \& $\mathrm{MACH}, \mathrm{J}$. The effect of colicin E2 on the flagellate Euglena gracilis 363

Eylan, E., see Lindenbaum, I., Eylan, E. \& RAANANI, E. Enhancement of growth of Leptospira icterohaemorrhagiae by tissue cell cultures $35^{8}$

Fox, R. F. \& McClain, D. E. Enzyme electrophoretograms in the analysis of taxon relatedness of Micrococcus cryophilus, Branhamella catarrhalis and atypical neisserias $2 \mathrm{IO}$

Gambacorta, A., see Millonig, G., de Rosa, M., Gambacorta, A. \& Bu'Lock, J. D. Ultrastructure of an extremely thermophilic acidophilic micro-organism 165

Gambacorta, A., see de Rosa, M., Gambacorta, A. \& Bu'Lock, J. D. Extremely thermophilic acidophilic bacteria convergent with Sulfolobus acidocaldarius $\mathbf{1 5 6}$

Gibbons, R. A., Jones, G. W. \& Sellwood, R. An attempt to identify the intestinal receptor for the $\mathrm{K} 88$ adhesin by means of a haemagglutination inhibition test using glycoproteins and fractions from sow colostrum 228

Goodell, E. W. \& Schwarz, U. Sphere-rod morphogenesis of Escherichia coli $20 \mathrm{I}$

Gower, J. C., see BarnetT, J. A., Bascomb, S. \& Gower, J. C. A maximal predictive classification of Klebsielleae and of the yeasts 93

Guest, J. R., see Watts, D. J. Studies on the vitamin nutrition of the cellular slime mould Dictyostelium discoideum 333

GüNTHER, T., RICHTER, L. \& SCHMALBECK, J. Phospholipids of Escherichia coli in magnesium deficiency 191 
Harder, W., Matin, A. \& AtTwood, M. M. Studies on the physiological significance of the lack of pyruvate dehydrogenase complex in Hyphomicrobium sp. 3 I9

Haskins, R. H., see Sietsma, J. H., Child, J. J., Nesbitt, L. R. \& Haskins, R. H. Chemistry and ultrastructure of the hyphal walls of Pythium acanthicum 29

Hedges, R. W., Rodriguez-Lemoine, V. \& Datta, N. R factors from Serratia marcescens 88

Hedges, R. W., see Rodriguez-Lemoine, V., JaCoB, A. E., Hedges, R. W. \& Datta, N. Thermosensitive production of their transfer systems by group S plasmids I I I

Hollingdale, M. R. Isolation of lipopolysaccharide from the walls of Micropolyspora faeni: chemical composition and serological reactivity 250

Holmgren, J. \& LönNRoth, I. Oligomeric structure of cholera toxin: characteristics of the $\mathrm{H}$ and $\mathrm{L}$ subunits 49

JaCob, A. E., see Rodriguez-Lemoine, V., JACob, A. E., Hedges, R. W. \& DatTa, N. Thermosensitive production of their transfer systems by group S plasmids II I

Jarvis, A. W., Lawrence, R. C. \& Pritchard, G. G. Glucose repression of enterotoxins A, B and $\mathrm{C}$ and other extracellular proteins in staphylococci in batch and continuous culture 75

Jones, G. W., see Gibbons, R. A., Jones, G. W. \& SELLwood, R. An attempt to identify the intestinal receptor for the K88 adhesin by means of a haemagglutination inhibition test using glycoproteins and fractions from sow colostrum 228

Kidby, D. K., see Murray, A. D. Sub-cellular location of mercury in yeast grown in the presence of mercuric chloride 66

Kinghorn, J. R. \& PATEMAN, J. A. Mutations which affect amino acid transport in Aspergillus nidulans I 74

Kinghorn, J. R. \& Pateman, J. A. The structural gene for NADP L-glutamate dehydrogenase in Aspergillus nidulans 294

Kiyomiya, A., see OHтA, K., Kiyomiya, A., Koyama, N. \& NosoH, Y. The basis of the alkalophilic property of a species of Bacillus 259

Koyama, N., see Ohta, K., Kiyomiya, A., Koyama, N. \& Nosoh, Y. The basis of the alkalophilic property of a species of Bacillus 259

Kurtz, M. \& Bhattacharjee, J. K. Biosynthesis of lysine in Rhodotorula glutinis: role of pipecolic acid 103

Lawn, A. M. \& Meynell, E. Extrusion of sex pili by rapidly washed $\mathrm{R}+$ Escherichia coli $\mathrm{I} 88$

LaWrence, R. C., see Jarvis, A. W., LaWrence, R. C. \& Pritchard, G. G. Glucose repression of enterotoxins $\mathrm{A}, \mathrm{B}$ and $\mathrm{C}$ and other extracellular proteins on staphylococci in batch and continuous culture 75

Lindendium, I., Eylan, E. \& RaAnani, E. Enhancement of growth of Leptospira icterohaemorrhagiae by tissue cell cultures $35^{8}$
LönnRoth, I., see Holmgren, J. Oligomeric structure of cholera toxin: characteristics of the $\mathbf{H}$ and L subunits 49

Loughlin, R. E. Polarity of the cys $J I H$ operon of Salmonella typhimurium 275

McCarthy, D. H. \& Rawle, C. T. The rapid serological diagnosis of fish furunculosis caused by 'smooth' and 'rough' strains of Aeromonas salmonicida I 85

McClain, D. E., see Fox, R. F. Enzyme electrophoretograms in the analysis of taxon relatedness of Microcococcus cryophilus, Branhamella catarrhalis and atypical neisserias 210

McCormick, D. B., see SHIH, J. C. H., Rozo, M. L., Wright, L. D. \& McCormick, D. B. Characterization of the growth of Pseudomonas putida LP on lipoate and its analogues: transport, oxidation, sulphur source and enzyme induction 217

MACH, J., see Šmarda, J., Ebringer, L. \& MACH, J. The effect of colicin E2 on the flagellate Euglena gracilis 363

Marchant, R., see Patton, A. M. The effect of cytochalasin $\mathrm{B}$ on hyphal morphogenesis in Polyporus biennis 301

MARRIOTT, M. S. Isolation and chemical characterization of plasma membranes from the yeast and mycelial forms of Candida albicans I 15

Matin, A., see Harder, W., Matin, A. \& AtTwooD, M. M. Studies on the physiological significance of the lack of a pyruvate dehydrogenase complex in Hyphomicrobium sp. 319

Merrick, M. J. \& Caten, C. E. The inheritance of penicillin titre in wild-type isolates of Aspergillus nidulans 283

Meynell, E., see LAwn, A. M. Extrusion of sex pili by rapidly washed $\mathrm{R}+$ Escherichia coli $\mathrm{I} 88$

Millonig, G., de Rosa, M., Gambacorta, A. \& Bu'Lock, J. D. Ultrastructure of an extremely thermophilic acidophilic micro-organism $\mathrm{I} 65$

Monti-Bragadin, C., Samer, L., Rottini, G. D. \& PANI, B. The compatibility of Hly factor, a transmissible element which controls $\alpha$-haemolysin production in Escherichia coli 367

Moseley, B. E. B. \& COPLAND, H. J. R. Involvement of a recombination repair function in disciplined cell division of Micrococcus radiodurans 343

MurRay, A. D. \& Kroby, D. K. Sub-cellular location of mercury in yeast grown in the presence of mercuric chloride 66

Nesbitt, L. R., see Sietsma, J. H., Chit.d, J. J., NesBitT, L. R. \& Haskins, R. H. Chemistry and ultrastructure of the hyphal walls of Pythium acanthicum 29

Nosoh, Y., see Ohta, K., Kiyomiya, A., Koyama, N. \& $\mathrm{NosoH}, \mathrm{Y}$. The basis of the alkalophilic property of a species of Bacillus 259

Ohta, K., Kiyomiya, A., Koyama, N. \& Nosoh, Y. The basis of the alkalophilic property of a species of Bacillus 259 
Pani, B., see Monti-Bragadin, C., Samer, L., Rottini, G. D. \& Pani, B. The compatibility of Hly factor, a transmissible element which controls $\alpha$-haemolysin production in Escherichia coli 367

Park, R. W. A., see Baker, D. A. Changes in morphology and cell wall structure that occur during growth of Vibrio sp. NCTC4716 in batch culture 12

Pateman, J. A., see Kinghorn, J. R. Mutations which affect amino acid transport in Aspergillus nidulans 174

Pateman, J. A., see Kinghorn, J. R. The structural gene for NADP L-glutamate dehydrogenase in Aspergillus nidulans 294

Patton, A. M. \& Marchant, R. The effect of cytochalasin $\mathbf{B}$ on hyphal morphogenesis in Polyporus biennis $30 \mathrm{I}$

Phillips, R. \& Butcher, D. N. Attempts to induce tumours with nucleic acid preparations from Agrobacterium tumefaciens $3 \mathrm{I} \mathbf{I}$

Pritchard, G. G., see Jarvis, A. W., Lawrence, R. C. \& Pritchard, G. G. Glucose repression of enterotoxins $\mathrm{A}, \mathrm{B}$ and $\mathrm{C}$ and other extracellular proteins in staphylococci in batch and continuous culture 75

RaANani, E., see LINDENBaum, I., EYlan, E. \& RAANANI, E. Enhancement of growth of Leptospira icterohaemorrhagiae by tissue cell cultures 358

RAWle, C. T., see MCCARThY, D. H. The rapid serological diagnosis of fish furunculosis caused by 'smooth' and 'rough' strains of Aeromonas salmonicida 185

Richter, L., see Günther, T., Richter, L. \& Schmalbeck, J. Phospholipids of Escherichia coli in magnesium deficiency I9I

Rodriguez-Lemoine, V., see Hedges, R. W., Rodriguez-Lemoine, V. \& DATTA, N. R factors from Serratia marcescens 88

Rodriguez-Lemoine, V., JacoB, A. E., Hedges, R.W. \& DATTA, N. Thermosensitive production of their transfer systems by group $\mathrm{S}$ plasmids I I I

de Rosa, M., Gambacorta, A. \& Bu'Lock, J. D. Extremely thermophilic acidophilic bacteria convergent with Sulfolobus acidocaldarius I 56

de Rosa, M., see Millonig, G., de Rosa, M., Gambacorta, A. \& Bu'Lock, J. D. Ultrastructure of an extremely thermophilic acidophilic micro-organism 165

Rottini, G. D., see Monti-Bragadin, C., SAmer, L., RotTini, G. D. \& Pani, B. The compatibility of Hly factor, a transmissible element which controls $\alpha$-haemolysin production in Escherichia coli 367
Rozo, M. L., see Sнiн, J. C. H., Rozo, M. L., Wright, L. D. \& McCormick, D. B. Characterization of the growth of Pseudomonas pudita LP on lipoate and its analogues: transport, oxidation, sulphur source and enzyme induction 217

Russell, D. W., see AudhyA, T. K. Enniatin production by Fusarium sambucinum: primary, secondary, and unitary metabolism 327

Samer, L., see Monti-Bragadin, C., Samer, L., RotTini, G. D. \& Pani, B. The compatibility of Hly factor, a transmissible element which controls $\alpha$-haemolysin production in Escherichia coli 367

Schmalbeck, J., see Günther, T., Richter, L. \& SCHMAlBECK, J. Phospholipids of Escherichia coli in magnesium deficiency $19 \mathrm{I}$

Schwartz, U., see Goodell, E. W. Sphere-rod morphogenesis of Escherichia coli $20 \mathrm{I}$

Sellwood, R., see Gibbons, R. A., Jones, G. W. \& Sellwood, R. An attempt to identify the intestinal receptor for the $\mathrm{K} 88$ adhesin by means of a haemagglutination inhibition test using glycoproteins and fractions from sow colostrum 228

ShiH, J. C. H., Rozo, M. L., Wright, L. D. \& McCormick, D. B. Characterization of the growth of Pseudomonas putida LP on lipoate and its analogues: transport, oxidation, sulphur source and enzyme induction 217

Sietsma, J. H., Child, J. J., Nesbitt, L. R. \& HASkINS, R. H. Chemistry and ultrastructure of the hyphal walls of Pythium acanthicum 29

SMarda, J., Ebringer, L. \& Mach, J. The effect of colicin $\mathrm{E}_{2}$ on the flagellate Euglena gracilis 363

Stormonth, D. A., see Coleman, G. Stimulation of the differential rate of exoenzyme formation in Bacillus amyloliquefaciens by streptolydigin, an inhibitor of RNA chain elongation 194

Tomasz, A., see Briles, E. B. Physiological studies on the pneumococcal Forssman antigen: a choline-containing lipoteichoic acid 267

Watrs, D. J. \& Guest, J. R. Studies on the vitamin nutrition of the cellular slime mould Dictyostelium discoideum 333

Wright, L. D., see SHih, J. C. H., Rozo, M. L., Wright, L. D. \& MCCoRMICK, D. B. Characterization of the growth of Pseudomonas putida LP on lipoate and its analogues: transport, oxidation, sulphur source and enzyme induction 217

Yamaguchi, H. Control of dimorphism in Candida albicans by zinc: effect on cell morphology and composition 370 


\section{Index of Subjects}

Aeromonas salmonicida, serological examination of 'smooth' and 'rough' strains (McCarthy \& Rowle) 185

Agrobacterium tumefaciens and tumour formation (Phillips \& Butcher) 3I I

AIkalophile, Bacillus species of (Ohta, Kiyomiya, Koyama \& Nosoh) 259

Amino acid transport in Aspergillus nidulans (Kinghorn \& Pateman) I74

Ammonia assimilation by Rhizobium and nodules (Brown \& Dilworth) 39

Antibiotic production by Fusarium sambucinum (Audhya \& Russell) 327

Antigen, Forssman, of pneumococcus (Briles \& Tomasz) 267

Aspergillus nidulans, inheritance of penicillin titre (Merrick \& Caten) 283

Aspergillus nidulans, mutations affecting amino acid transport in (Kinghorn \& Pateman) 174

Aspergillus nidulans, structural gene for NADP Lglutamate dehydrogenase (Kinghorn \& Pateman) 294

Bacillus, alkalophilic species (Ohta, Kiyomiya, Koyama \& Nosoh) 259

Bacillus amyloliquefaciens, effect of streptolydigin on exoenzyme formation (Coleman \& Stormonth) 194

Bisnor-lipoic acid, bacterial metabolism (Shih, Rozo, Wright \& McCormick) $2 \mathrm{I} 7$

Branhamella catarrhalis, enzyme electrophoretograms in taxonomy of (Fox \& McClain) 210

Candida albicans, effect of zinc on composition and dimorphism (Yamaguchi) 370

Candida albicans, plasma membranes from yeast and mycelial forms (Marriott) II 5

Carbon sources for Hyphomicrobium sp. (Harder, Matin \& Attwood) 319

Cell division in Micrococcus radiodurans (Moseley \& Copland) 343

Chlorophyll synthesis in Euglena gracilis, inhibition by colicin E2 (Šmarda, Ebringer \& Mach) 363

Cholera toxin, $\mathrm{H}$ and $\mathrm{L}$ subunits of (Holmgren \& Lönnroth) 49

Chromosome transfer in Proteus mirabilis (Coetzee) I 33

Clamp connexions, effect of cytochalasin $\mathrm{B}$ on (Patton \& Marchant) 30I

Classification, maximal predictive, for yeasts and Klebsielleae (Barnett, Bascomb \& Gower) 93

Coenzymes of fusobacteria (Coles) 147

Colicin E2, effect on Euglena gracilis (Šmarda, Ebringer \& Mach) 363

Compatibility of Hly factor (Monti-Bragadin, Samer, Rottini \& Pani) 367

Conjugation in Proteus mirabilis (Coetzee) 133

CysJIH operon of Salmonella typhimurium, polarity of (Loughlin) 275
Cytochalasin B, effect of Polyporus biennis (Patton \& Marchant) 301

Dictyostelium discoideum, vitamin nutrition (Watts \& Guest) 333

Dimorphism in Candida albicans, effect of zinc (Yamaguchi) 370

Enniatin production by Fusarium sambucinum (Audhya \& Russell) 327

Enterotoxins, staphylococcal, effect of glucose and growth rate on (Jarvis, Lawrence \& Pritchard) 75

Escherichia coli, compatibility of Hly factor (MontiBragadin, Samer, Rottini \& Pani) 367

Escherichia coli, extrusion of sex pili by (Lawn \& Meynell) 188

Escherichia coli $\mathrm{K} 88$ receptor, identification by haemagglutination inhibition test (Gibbons, Jones \& Sellwood) 228

Escherichia coli, magnesium deficiency and phospholipid content in (Günther, Richter \& Schmalbeck) 191

Escherichia coli, sphere-rod morphogenesis of (Goodell \& Schwarz) 20I

Euglena gracilis, effect of colicin E2 on (Šmarda, Ebringer \& Mach) 363

Exoenzyme formation in Bacillus amyloliquefaciens (Coleman \& Stormonth) 194

Forssman antigen of pneumococcus, physiology (Briles \& Tomasz) 267

Furunculosis and rapid identification of Aeromonas salmonicida (McCarthy \& Rowle) I 85

Fusarium sumbucinum, enniatin production by (Audhya \& Russell) $\mathbf{3 2 7}$

Fusobacterium, coenzyme leakage from (Coles) 147

Genetics of penicillin titre in Aspergillus nidulans (Merrick \& Caten) 283

L-Glutamate dehydrogenase, NADP, in Aspergillus nidulans, structural gene for (Kinghorn \& Pateman) 294

Glutamine synthetase and glutamate synthase in Rhizobium (Brown \& Dilworth) 39

Glucose, repression of extracellular proteins in staphylococci by (Jarvis, Lawrence \& Pritchard) 75

Growth of Leptospira icterohaemorrhagiae, enhancement by tissue cell cultures (Lindenbaum, Eylan \& Raanani) 358

Haemagglutination by $\mathrm{K} 88$ adhesin and glycoprotein inhibition (Gibbons, Jones \& Sellwood) 228

Heterokaryon incompatibility, relationship to penicillin yield in Aspergillus nidulans (Merrick \& Caten) 283

Hly factor, compatibility of (Monti-Bragadin, Samer, Rottini \& Pani) 367 
Hyphae of Polyporus biennis, effect of cytochalasin B on morphogenesis of (Patton \& Marchant) $30 \mathrm{I}$

Hyphae of Pythium acanthicum, compositon of walls (Sietsma, Child, Nesbitt \& Haskins) 29

Hyphomicrobium sp., pyruvate dehydrogenase deficiency in (Harder, Matin \& Attwood) 319

Isocitrate lyase, regulation of synthesis in Neurospora crassa (Beever) 197

K88 antigen, inhibition of haemagglutination by sow colostrum (Gibbons, Jones \& Sellwood) 228

Klebsielleae, a maximal predictive classification of (Barnett, Bascomb \& Gower) 93

Leakage of coenzymes from fusobacteria (Coles) I47

Leptospira icterohaemorrhagiae, growth enhancement by tissue cell cultures (Lindenbaum, Eylan \& Raanani) 358

Lipoic acid, metabolism by Pseudomonas putida LP (Shih, Rozo, Wright \& McCormick) 217

Lipopolysaccharide from walls of Micropolyspora faeni, composition and serological reactivity (Hollingdale) 250

Lipoteichoic acid of pneumococcus, physiology of (Briles \& Tomasz) 267

Lysine biosynthesis in Rhodotorula glutinis, role of pipecolic acid in (Kurtz \& Bhattacharjee) 103

Magnesium deficiency and phospholipid composition in Escherichia coli (Günther, Richter \& Schmalbeck) I9 I

Membranes, plasma, from yeast and mycelial forms of Candida albicans (Marriott) II 5

Mercury, sub-cellular location in yeast (Murray \& Kidby) 66

Metabolism and enniatin production by Fusarium sambucinum (Audhya \& Russell) 327

Micrococcus cryophilus, enzyme electrophoretograms in taxonomy of (Fox \& McClain) 210

Micrococcus radiodurans, recombination repair and cell division in (Moseley \& Copland) 343

Micropolyspora faeni, lipopolysaccharide from walls (Hollingdale) 250

Morphogenesis in Vibrio NCTC4716 (Baker \& Park) I 2

Mutations affecting amino acid transfer in Aspergillus nidulans (Kinghorn \& Pateman) 174

Neisserias, atypical, enzyme electrophoretograms in taxonomy of (Fox \& McClain) 210

Neurospora crassa, 2-phosphoenolpyruvate carboxykinase and isocitrate lyase synthesis (Beever) 197

Nodules, ammonia assimilation in (Brown \& Dilworth) 39

Nucleic acid from Agrobacterium tumefaciens, and tumour induction (Phillips \& Butcher) 311

Penicillin FL-1060, formation of spheres of Escherichia coli with (Goodell \& Schwarz) 20 I

Penicillin, inheritance of titre in Aspergillus nidulans

(Merrick \& Caten) 283

Peptidoglycan in walls of Vibrio NCTC47 6 (Baker \& Park) 12
2-Phosphoenolpyruvate carboxykinase, regulation of synthesis in Neurospora crassa (Beever) 197

Phospholipids in magnesium-deficient Escherichia coli (Günther, Richter \& Schmalbeck) I9 I

Pili, sex, extrusion by rapidly washed $\mathrm{R}^{+}$Escherichia coli (Lawn \& Meynell) 188

Pipecolic acid, role in lysine biosynthesis in Rhodotorula glutinis (Kurtz \& Bhattacharjee) IO3

Plasma membranes from yeast and mycelial forms of Candida albicans (Marriott) 115

Plasmids from Serratia marcescens (Hedges, Rodriguez-Lemoine \& Datta) 88

Plasmids, group S, thermosensitive transfer system (Rodriguez-Lemoine, Jacob, Hedges \& Datta) II I

Plasmids in Proteus mirabilis (Coetzee) 133

Pneumococcus, Forssman antigen of (Briles \& Tomasz) 267

Polarity of the cysJIH operon (Loughlin) 275

Polyporus biennis, cytochalasin B and hyphal morphogenesis (Patton \& Marchant) 301

Proteins of staphylococci, extracellular, effect of glucose and growth rate on (Jarvis, Lawrence \& Pritchard) 75

Proteus mirabilis, chromosome transfer in (Coetzee) I 33

Pseudomonas putida LP, metabolism of lipoate and analogues (Shih, Rozo, Wright \& McCormick) 217

Pyruvate dehydrogenase deficiency in Hyphomicrobium sp. (Harder, Matin \& Attwood) 319

Pythium acanthicum, hyphal wall composition (Sietsma, Child, Nesbitt \& Haskins) 29

Radiation and cell division in Micrococcus radiodurans (Moseley \& Copland) 343

Recombination and cell division in Micrococcus radiodurans (Moseley \& Copland) 343

Respiration apparatus in sugar-tolerant and nontolerant yeasts (Brown) 24I

$\mathrm{R}$ factors from Serratia marcescens (Hedges, Rodriguez-Lemoine \& Datta) 88

Rhizobium, ammonia assimilation by (Brown \& Dilworth) 39

Rhodotorula glutinis, lysine biosynthesis in (Kurtz \& Bhattacharjee) 103

Salmonella typhimurium, polarity of the cysJIH operon (Loughlin) 275

Serology, rapid examination of 'smooth' and 'rough' strains of Aeromonas salmonicida (McCarthy \& Rowle) 185

Serratia marcescens, plasmids from (Hedges, Rodriguez-Lemoine \& Datta) 88

Spheroplasts of Escherichia coli, morphogenetic capacity of (Goodell \& Schwarz) 201

$S$ plasmids, thermosensitive transfer system (Rodriguez-Lemoine, Jacob, Hedges \& Datta) I I I

Staphylococci, glucose repression of extracellular proteins of (Jarvis, Lawrence \& Pritchard) 75

Streptolydigin, stimulation of exoenzyme formation in Bacillus amyloliquefaciens by (Coleman \& Stormonth) I94 
Sulfolobus acidocaldarius, acidophilic thermophiles convergent with (de Rosa, Gambacorta \& Bu'Lock) 156

Taxonomy of Microccoccus cryophilus, Branhamella catarrhalis and atypical neisserias (Fox \& McClain) 2 IO

Temperature, effect on transfer of group S plasmids (Rodriguez-Lemoine, Jacob, Hedges \& Datta) I I I

Tetranor-lipoic acid, bacterial metabolism (Shih, Rozo, Wright \& McCormick) 217

Thermophile, acidophilic, ultrastructure of (Millonig, de Rosa, Gambacorta \& Bu'Lock) 165

Thermophiles, acidophilic, convergent with Sulfolobus acidocaldarius (de Rosa, Gambacorta \& Bu'Lock) 156

Tissue cultures, effect on leptospires (Lindenbaum, Eylan \& Raanani) 358

Toralopsis, new species from fruit (Buhagiar) I

Toxin, cholera, $\mathrm{H}$ and $\mathbf{L}$ subunits of (Holmgren \& Lönnroth) 49

Transfer of group S plasmids, thermosensitivity of (Rodriguez-Lemoine, Jacob, Hedges \& Datta) I I I

Transport of amino acids in Aspergillus nidulans (Kinghorn \& Pateman) 174

Tumour induction by Agrobacterium tumefaciens (Phillips \& Butcher) 3 I I
Ultrastructure of thermophilic acidophilic microorganisms (Millonig, de Rosa, Gambacorta \& Bu'Lock) 165

Vibrio NCTC4716, morphological changes in (Baker \& Park) 12

Vitamin nutrition of Dictyostelium discoideum (Watts \& Guest) 333

Walls, hyphal, composition in Pythium acanthicum (Sietsma, Child, Nesbitt \& Haskins) 29

Walls of Vibrio NCTC47 I6, changes in peptidoglycan layer (Baker \& Park) I2

Water relations of sugar-tolerant yeasts (Brown) $24 \mathrm{I}$

Yeasts, a maximal predictive classification of (Barnett, Bascomb \& Gower) 93

Yeasts, new species of Torulopsis from fruit (Buhagiar) $I$

Yeasts, sugar-tolerant and non-tolerant, respiratory apparatus in (Brown) 24I

Yeast, subcellular location of mercury in (Murray \& Kidby) 66

Zinc, effect on composition and dimorphism of Candida albicans (Yamaguchi) 370 